\title{
Efikasi Herbisida Isopropilamina Glifosat terhadap Pengendalian Gulma Kelapa Sawit Belum Menghasilkan
}

\section{Efication of Isopropilamina Glifosat in Herbicide to Control The Weeds of Immature Palm Oil}

\author{
Venti Jatsiyah $^{* 1}$ dan Sarwendah Ratnawati Hermanto ${ }^{1}$ \\ ${ }^{1}$ Program Studi Budidaya Tanaman Perkebunan, Politeknik Negeri Ketapang \\ *Email korespondensi: ventijatsiyah@gmail.com
}

Diterima: 11 Desember 2019 / Disetujui: 09 Maret 2020

\begin{abstract}
One of the factors that inhibits palm oil productivity is weeds, because weeds are not directly visible and generally run slowly. Chemical control methods using herbicides are considered the easiest method. This study aims to determine the effective dose of herbicide and to determine the level of weed mortality after application of glyphosate isopropylamine herbicide in immature oil palm plantations (TBM). This research was conducted in the area of immature oil palm plantations (TBM) in the Pelang village plantation, Ketapang Regency, West Kalimantan. This study used a randomized block design (RBD) with 6 treatments and 4 replications. The results showed that the isopropylamine glyphosate was able to suppress weed growth. Based on the results of the duncan multiple range test (DMRT) the best treatment in controlling weeds in immature oil palm plants is at a dose of $2.00 \mathrm{~L} \mathrm{Ha}^{-1}$, able to effectively suppress weed growth with a concentration of $1.7 \%$ in reducing the total weed dry weight in 2 and 6 MSA in immature oil palm plants (TBM).
\end{abstract}

Keywords: concentration, dosage, weed

\section{ABSTRAK}

Salah satu faktor yang menghambat produktivitas kelapa sawit yaitu gulma, karena pengaruh gulma tidak terlihat secara langsung dan umumnya berjalan lambat. Metode pengendalian secara kimiawi dengan menggunakan herbisida dianggap sebagai metode paling mudah. Penelitian ini bertujuan untuk mengetahui dosis herbisida yang efektiv serta mengetahui tingkat kematian gulma setelah aplikasi herbisida isopropilamina glifosat pada perkebunan kelapa sawit belum menghasilkan (TBM). Penelitian ini dilaksanakan pada area perkebunan kelapa sawit belum menghasilkan (TBM) di perkebunan desa Pelang, Kabupaten Ketapang, Provinsi Kalimantan Barat. Penelitian ini menggunakan rancangan acak kelompok (RAK) dengan 6 perlakuan serta 4 ulangan. Hasil penelitian menunjukan bahwa herbisida isopropilamina glifosat mampu menekan pertumbuhan gulma. Berdasarkan hasil uji duncan multiple range test (DMRT) perlakuan terbaik dalam pengendalian gulma di tanaman kelapa sawit belum menghasilkan yaitu pada dosis 2,00 l/ha, mampu menekan pertumbuhan gulma secara efektif dengan konsentrasi 1,7\% dalam menurunkan bobot kering gulma total pada 2 dan 6 MSA di tanaman kelapa sawit belum menghasilkan (TBM).

Kata kunci: dosis, gulma, konsentrasi

\section{PENDAHULUAN}

Tanaman kelapa sawit (Elaeis guineensis Jacq.) merupakan komoditas perkebunan yang banyak dibudidayakan di Indonesia baik oleh perkebunan milik pemerintah, swasta, maupun perkebunan rakyat. Komoditas ini banyak diminati karena produk utamanya yaitu CPO (Crude Palm Oil) atau minyak sawit mentah merupakan produk yang memiliki nilai ekonomis yang tinggi. Minyak mentah ini dapat dimanfaatkan menjadi berbagai produk turunan dalam industri makanan, farmasi, dan kosmetik. Selain itu, limbah dari industri ini pun masih dapat dimanfaatkan sebagai bahan bakar, bahan baku industri mebel, oleokimia, dan pakan ternak (Y, Widyastuti, Satyawibawa, \& Paeru, 2012) .
Gulma pada tanaman kelapa sawit dapat menurunkan produktivitas, seperti gulma Mikania micrantha dapat menurunkan produksi TBS sebesar 20\% (Kementrian Pertanian. 2013). Pengendalian Ischaemum muticum (L.), jenis gulma rerumputan tahunan, mampu meningkatkan bobot buah segar sekitar 10 ton/ha dalam waktu tiga tahun. Mengingat besarnya pengaruh gulma terhadap produksi tanaman, maka diperlukan adanya pengendalian gulma yang tepat.

Gulma dalam perkebunan kelapa sawit tidak dikehendaki karena dapat mengakibatkan menurunnya produksi akibat persaingan dalam pengambilan unsur hara, sinar matahari, air, ruang hidup dan menjadi inang (host) bagi hama, di samping patogen yang menyerang tanaman (J M. , 2010). 
Herbisida glifosat memiliki spektrum pengendalian luas, diaplikasikan pascatumbuh, dan bersifat sistemik (A, Baillie, Thompson, \& Little, 2017). Herbisida berbahan aktif Isopropilamina glifosat mampu menekan pertumbuhan gulma total maupun pergolongan dan efektif mengendalikan gulma, contohnya gramineae yaitu jenis gulma rumputrumputan, salah satunya ialah Paspalum conjugatum berg (rumput paitan) serta aplikasi herbisida pada gulma kelapa sawit belum menghasilkan (TBM) diperoleh hasil bahwa dosis herbisida Isopropilamina glifosat 2,25 L/ha, 3,0 L/ha, 3,75 L/ha, 4,50 L/ha, 5,25 L/ha dapat menurunkan bobot kering gulma jika dibandingkan dengan bobot kering gulma pada petak perlakuan kontrol (Pasaribu, R., Wicaksono, K.P., dan Tyasmoro, S.Y. 2017).

Berdasarkan latar belakang penelitian di atas maka urgensi dari diadakannya penelitian ini adalah didapatkan informasi mengenai dosis herbisida yang efektif dalam mengendalikan gulma namun lebih efisien penggunaannya. Hal ini dikarenakan semakin efisien dosis herbisida yang digunakan untuk mengendalikan gulma akan menguntungkan petani ataupun perusahaan karena biaya pemeliharaan kebun yang semakin rendah.

\section{BAHAN DAN METODE}

\section{Bahan}

Pada penelitian ini bahan-bahan yang digunakan yaitu air dan herbisida berbahan aktif isopropilamina glifosat 480g/L (setara dengan glifosat 356g/L) dengan merek dagang Kleen up 480 SL. Sedangkan alat-alat yang digunakan yaitu knapsack sprayer semi automatic, nozel biru, gelas ukur, ember, nampan, kuadran berukuran $0,5 \mathrm{~m} \mathrm{x}$ $0,5 \mathrm{~m}$, arit/cangkul, meteran, label, oven, timbangan, tali rafia dan alat pembantu yang diperlukan untuk penelitian.

\section{Metode}

Penelitian ini dilaksanakan menggunakan rancangan acak kelompok (RAK) dengan 6 perlakuan serta 4 ulangan. Sehingga diperoleh 24 satuan percobaan tanaman kelapa sawit belum menghasilkan (TBM).
Adapun perlakuan yang digunakan yaitu :

K0 = Tanpa disemprot herbisida (kontrol)

$\mathrm{K} 1$ = Penggunaan herbisida glifosat dosis 2,00 L/ha $(0,4$ $\mathrm{mL} /$ petak)

$\mathrm{K}_{2}$ = Penggunaan herbisida glifosat dosis 2,25 L/ha (0,45 $\mathrm{mL} /$ petak)

$\mathrm{K} 3$ = Penggunaan herbisida glifosat dosis 2,50 L/ha (0,5 $\mathrm{mL} /$ petak)

K4 = Penggunaan herbisida glifosat dosis $2,75 \mathrm{~L} / \mathrm{ha}(0,55$ $\mathrm{mL} /$ petak)

$\mathrm{K} 5$ = Penggunaan herbisida glifosat dosis 3,00 L/ha $(0,6$ $\mathrm{mL}$ / petak)

Pemilihan lokasi dan penetapan blok yang akan digunakan sebagai lahan percobaan yaitu di perkebunan kelapa sawit yang belum menghasilkan. Masing-masing plot berukuran $1 \mathrm{~m}$ x $2 \mathrm{~m}$, kemudian plot dibuat pembatas menggunakan tali rafia atau potongan kayu.

\section{Pengamatan}

Identifikasi gulma pada plot setelah aplikasi dan analisa data. Untuk pengambilan contoh gulma dilakukan menggunakan kuadran berukuran $0,5 \mathrm{~m}$ x $0,5 \mathrm{~m}$ pada dua titik pengambilan berbeda yaitu 4 dan 8 MSA. Gulma yang berada di dalam petak kuadran dipotong tepat pada permukaan tanah. Selanjutnya, gulma dikelompokkan berdasarkan jenisnya dan dikeringkan dengan menggunakan oven pada suhu $80^{\circ} \mathrm{C}$ selama 2 × 24 jam (bobot sampel konstan), kemudian ditimbang. Sementara itu untuk identifikasi gulma dilakukan setelah aplikasi untuk keperluan analisis vegetasi. Kemudian dilakukan perhitungan Summed Dominance Ratio (SDR) untuk menentukan jenis dan urutan gulma dominan yang ada di lahan kelapa sawit belum menghasilkan.

Setelah data yang diperoleh dari hasil pengamatan dianalisis dengan menggunakan sidik ragam atau uji $F$ pada taraf kesalahan 5\% untuk mengetahui interaksi di antara perlakuan dan dilanjutkan dengan Uji Duncan Multiple Range Test (DMRT), apabila terdapat perbedaan yang nyata antar perlakuan.

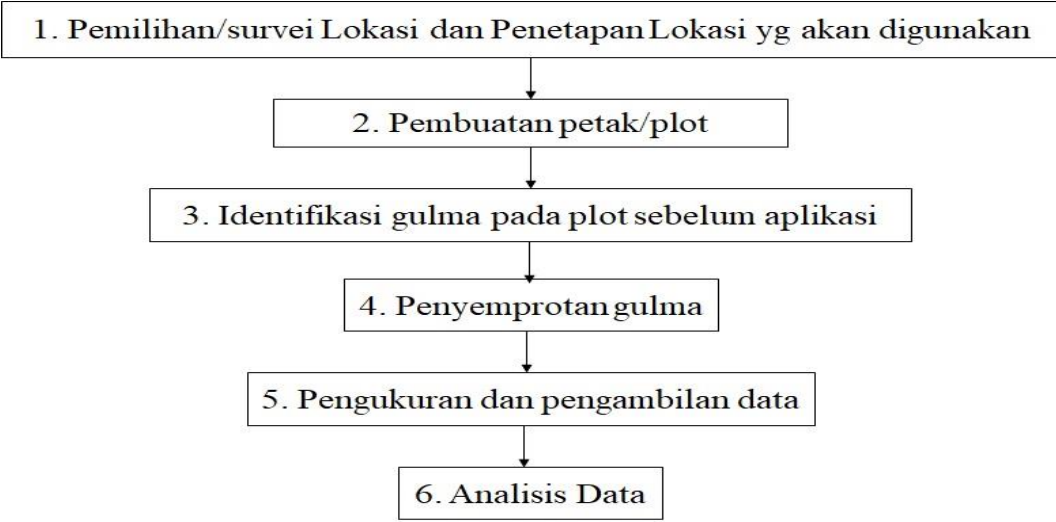

Gambar 1. Diagram Alir Lngkah-Langkah Penelitian. 


\section{HASIL DAN PEMBAHASAN}

\section{Skoring Kematian Gulma}

Hasil pengujian penyemprotan herbisida isopropilamina glifosat memberikan pengaruh nyata terhadap intensitas kerusakan gulma. Intensitas kerusakan pada masing-masing perlakuan sudah mulai terlihat tiga hari setelah aplikasi. Intensitas kerusakan gulma pada semua perlakuan dapat dilihat pada Tabel 1 dan Gambar 2.

Hasil pengamatan intensitas kerusakan gulma mulai terlihat pada saat 3 hari setelah aplikasi penyemprotan herbisida isopropilamina glifosat. Intensitas kerusakan gulma mulai terlihat pada pengamatan 3 hari setelah aplikasi penyemprotan menunjukkan intensitas yang cukup tinggi terhadap semua perlakuan. Terlihat, dimana persentase kematian gulma pada pengamatan hari pertama menyebabkan kerusakan yang sangat ringan yaitu hanya $1 \%$ pada perlakuan $\mathrm{K}_{1}$, namun pada hari kedua tingkat kematian gulma mencapai $20 \%$. Gejala keracunan gulma terlihat cukup tinggi pada hari ke-6 setelah aplikasi penyemprotan terutama gulma golongan daun lebar.

Pengaruh pemberian herbisida glifosat terhadap semua perlakuan pada setiap 3 hari pengamatan menunjukkan gejala keracunan yang tinggi hingga mencapai $100 \%$ gulma mati total dengan menunjukkan gejala keracunan sangat berat hingga akhir pengamatan. Hal tersebut menunjukkan efikasi herbisida glifosat memuaskan dalam kurun waktu bersamaan yaitu pada hari ke-3 dan hari ke-18 setelah aplikasi. Hal ini sesuai dengan pengujian taraf dosis yang sudah dilakukan bahwa, efektivitas herbisida bersifat relatif tergantung tingkat konsentrasi dan dosis yang digunakan. Glifosat merupakan herbisida yang memiliki spektrum pengendalian luas, diaplikasikan pascatumbuh, dan bersifat sistemik (Rolando et al., 2017). Herbisida yang diaplikasikan dalam dosis tinggi akan menyebabkan kematian pada seluruh bagian dan jenis tumbuhan, tetapi apabila herbisida diaplikasikan dengan dosis rendah maka akan membunuh tumbuhan tertentu saja dan tidak merusak tumbuhan lainnya (Sembodo, 2010).

Tingkat konsentrasi herbisida isopromilamina glifosat yaitu semakin tinggi konsentrasi herbisida akan meningkatkan indeks aktivitas herbisida, yang berarti efek fitotoksisitas lebih besar sehingga tingkat kematian gulma lebih tinggi. Gambar 2 menunjukkan persentase kematian gulma dari semua perlakuan mengalami intensitas kerusakan cukup tinggi yaitu rerata sebesar $8,79 \%$ pada perlakuan $\mathrm{K}_{1}$ pengamatan dan pada perlakuan $\mathrm{K}_{3}$ rerata intensitas kerusakan gulma yaitu $10,46 \%$ pada setiap hari pengamatan yang dilakukan setiap 3 hari sekali selama 18 hari. Gejala keracunan glifosat akan terlihat pada 2-4 hari setelah aplikasi pada gulma semusim dan 7-20 hari untuk gulma musiman (Sembodo, 2010)

Gejala kerusakan daun gulma contohnya gulma Scleria sumatrensis yang diamati secara visual adalah kerusakan daun mulai terlihat pada hari pertama pengamatan dimana daun yang semula berwarna hijau mengalami nekrosis (kematian) daun mulai menguning dan terdapat bercak-bercak putih pada daun tersebut, lalu gulma tersebut mengalami nekrosis melebar yaitu berubah menjadi kuning yang pada akhirnya menjadi kecoklatan.

Gejala keracunan gulma terlihat sangat nyata pada taraf dosis perlakuan $\mathrm{K}_{5}$, dimana pada pengamatan pertama (3 hari setelah aplikasi) menunjukan angka kematian gulma mencapai $5 \%$, namun dosis yang lebih rendah yaitu pada perlakuan $\mathrm{K}_{1}$ sudah menunjukan angka yang signifikan maka lebih baik menggunakan dosis dengan konsentrasi rendah yaitu konsentrasi $1,7 \quad \% \quad$ (dosis $2,00 \quad \mathrm{~L} / \mathrm{ha}$ ) dibandingkan penggunaan dosis lebih tinggi untuk mengendalikan gulma di tanaman kelapa sawit, maka dosis terbaik yang di gunakan dalam penelitian ini yaitu dosis 2,00 L/ha. Tingkat dosis aplikasi herbisida menentukan efektivitas penggunaan herbisida untuk mengendalikan gulma.

Tabel 1. Rerata intensitas kerusakan gulma pada tiap hari pengamatan terhadap semua ulangan

\begin{tabular}{ccccccc}
\hline \multirow{2}{*}{ Perlakuan } & \multicolumn{7}{c}{ \% Rerata Intensitas Kerusakan Pada Hari Ke- } \\
\cline { 2 - 6 } & 3 & 6 & 9 & 12 & 15 & 18 \\
\hline Kontrol & 0 & 0 & 0 & 0 & 0 & 0 \\
$\mathrm{~K}_{1}$ & 0,01 & 0,18 & 50,1 & 70,75 & 95,75 & 100 \\
$\mathrm{~K}_{2}$ & 0,05 & 0,15 & 50,15 & 85,75 & 95,85 & 100 \\
$\mathrm{~K}_{3}$ & 0,01 & 0,2 & 80,75 & 95,75 & 98,85 & 100 \\
$\mathrm{~K}_{4}$ & 0,03 & 0,15 & 75,85 & 95,55 & 99,85 & 100 \\
$\mathrm{~K}_{5}$ & 0,04 & 0,1 & 50,25 & 75,85 & 90,75 & 100 \\
\hline
\end{tabular}




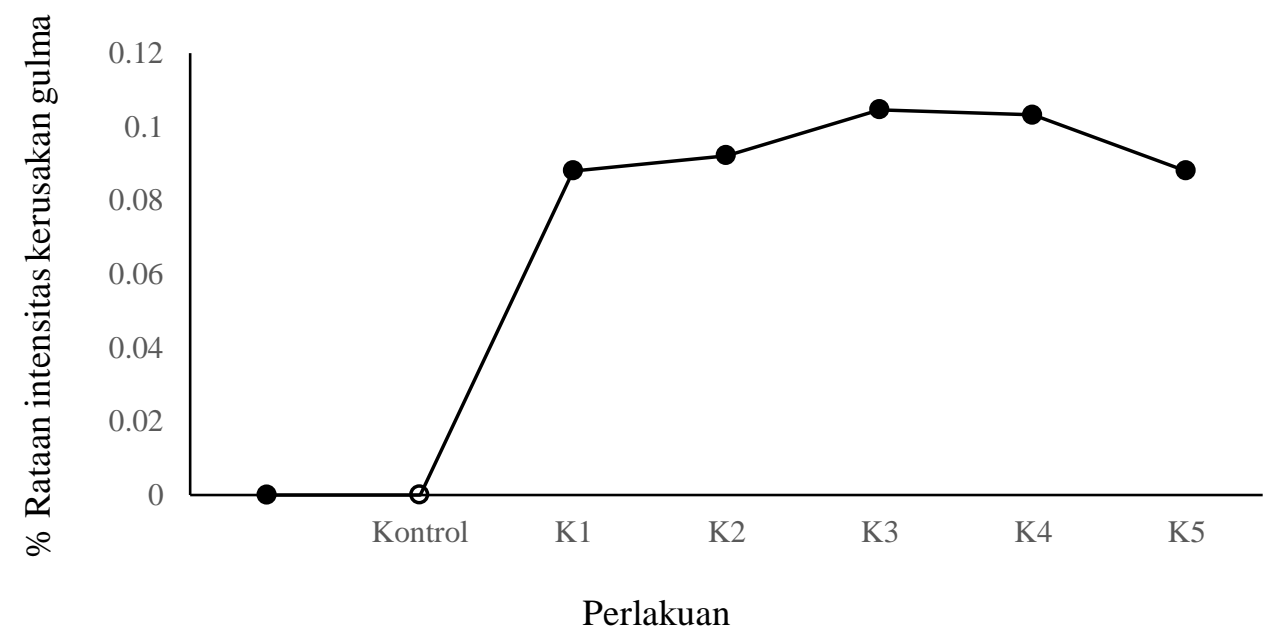

Gambar 1. Rataan intensitas kerusakan gulma pada berbagai perlakuan terhadap semua ulangan.

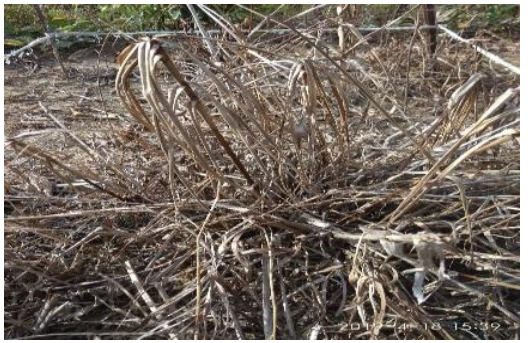

(a) 3 hari setelah aplikasi

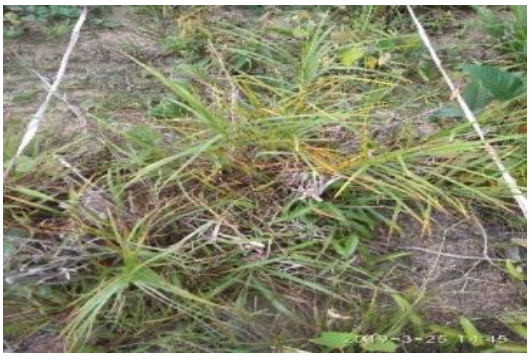

(b) 18 hari setelah aplikasi

Gambar 2. Gulma Scleria sumatrensis mengalami nekrosis pada daun mulai menguning 3 HSA (a) dan gulma mengalami nekrosis melebar menjadi kuning hingga kecoklatan 18 HSA (b).

Penggunaan dosis aplikasi yang terlalu rendah menyebabkan tujuan pengendalian tidak berhasil. Sebaliknya bila dosis aplikasi terlalu tinggi, di samping terjadi pemborosan, juga akan menimbulkan masalah pencemaran lingkungan. Selain masalah pencemaran lingkungan dosis aplikasi yang terlalu tinggi dapat menimbulkan keracunan bagi tanaman budidaya (fitotoksisitas). Herbisida ini diabsorbsi oleh daun dan ditranslokasikan dalam tumbuhan yang berlangsung secara sistemik, yaitu melalui jaringan hidup dan pembuluh utama floem menuju ke jaringan meristem (Sriyani, 2016). Isopropilamina glifosat merupakan herbisida pasca tumbuh yang diformulasi dalam bentuk larutan yang mudah larut dalam air yang dapat mengendalikan gulma berdaun sempit, berdaun lebar, dan teki-tekian serta mempunyai spektrum yang luas.

Selain itu herbisida ini cukup efektif untuk mengendalikan gulma semak berkayu. Setelah herbisida diaplikasikan, herbisida glifosat yang tidak mengenai sasaran atau tercecer akan segera diabsorbsi oleh tanah dan cenderung sulit tercuci. Waktu rata-rata dari herbisida glifosat dalam tanah adalah 60 hari. Sembodo (2010) menyatakan bahwa gulma dari spesies yang sama pun kadangkala memberikan respon yang berbeda terhadap herbisida tertentu, apalagi antar jenis gulma walaupun dalam satu golongan tertentu, respon yang ditunjukkan sering berbeda.

\section{Bobot basah dan kering gulma}

Pengamatan terhadap bobot basah dan kering dilakukan setelah akhir penelitian yaitu setelah 2 dan 6 minggu pengamatan. Penimbangan berat kering dilakukan setelah gulma dikering ovenkan hingga menunjukkan berat konstan yang kemudian ditimbang. Data yang diperoleh kemudian dihitung untuk mengetahui perbedaan antar perlakuan penyemprotan herbisida isopropilamina glifosat.

Tabel ANOVA di atas merupakan hasil analisis untuk data bobot basah dan kering gulma pada 2 MSA dan 6 MSA. Hasilnya menunjukkan bahwa berpengaruh nyata jika angka P Value (ditandai dengan $\mathrm{Pr}>\mathrm{F}$ ) dari perlakuan (glifosat) sebesar 0,0181 yang berarti $<_{\text {alpha }}=0,05$ dan berpengaruh sangat nyata apabila dari perlakuan (glifosat) sebesar 0,0013 yang berarti <alpha $=0,05$. Berdasarkan hasil analisis keragaman (ANOVA) pada Tabel 2 sampai Tabel 5 menunjukkan bahwa perlakuan penyemprotan herbisida isopropilamina glifosat berpengaruh sangat nyata terhadap bobot basah gulma pada pengamatan 2 dan $6 \mathrm{MSA}$, dan bobot kering pada pengamatan $6 \mathrm{MSA}$, sedangkan pada pengamatan 2 MSA berpengaruh nyata terhadap bobot kering gulma, untuk mengetahui taraf mana yang menunjukkan perbedaan yang nyata dari masing-masing perlakuan maka dilakukan uji Duncan Multiple Range Test (DMRT). 
Tabel 2. Analisis keragaman (ANOVA) penyemprotan herbisida isopropilamina glifosat terhadap bobot basah gulma 2 MSA.

\begin{tabular}{lccccc}
\hline Sumber keragaman & $\mathrm{db}$ & Jumlah kuadrat & $\begin{array}{c}\text { Kuadrat } \\
\text { tengah }\end{array}$ & F Hit & Pr $>$ F \\
\hline Ulangan & 3 & 27,76 & 9,25 & 1,27 & 0,3210 \\
Perlakuan glifosat & 5 & 260,64 & 52,12 & 7,14 & $0,0013 * *$ \\
Galat & 15 & 109,48 & 7,29 & & \\
\hline Total & 23 & 397,89 & & & \\
\hline
\end{tabular}

$\mathrm{Kk}=11,813 \%$

Keterangan : Jika P Value <alpha 0,05 maka berpengaruh sangat nyata $(* *)$ pada taraf $5 \%$

Tabel 3. Analisis keragaman (ANOVA) penyemprotan herbisida isopropilamina glifosat terhadap bobot kering gulma 2 MSA.

\begin{tabular}{lccccc}
\hline Sumber keragaman & $\mathrm{db}$ & Jumlah kuadrat & Kuadrat tengah & $\mathrm{F} \mathrm{Hit}$ & Pr $>$ F \\
\hline Ulangan & 3 & 29,23 & 9,74 & 2,18 & 0,1325 \\
Perlakuan glifosat & 5 & 87,28 & 17,45 & 3,91 & $0,0181^{*}$ \\
Galat & 15 & 66,95 & 4,46 & & \\
& & & & \\
\hline Total & 23 & 183,47 & & \\
\hline
\end{tabular}

$\mathrm{Kk}=10,710 \%$

Keterangan : Jika P Value <alpha 0,05 maka berpengaruh nyata $(*)$ pada taraf $5 \%$.

Tabel 4. Analisis keragaman (ANOVA) penyemprotan herbisida isopropilamina glifosat terhadap bobot basah gulma 6 MSA.

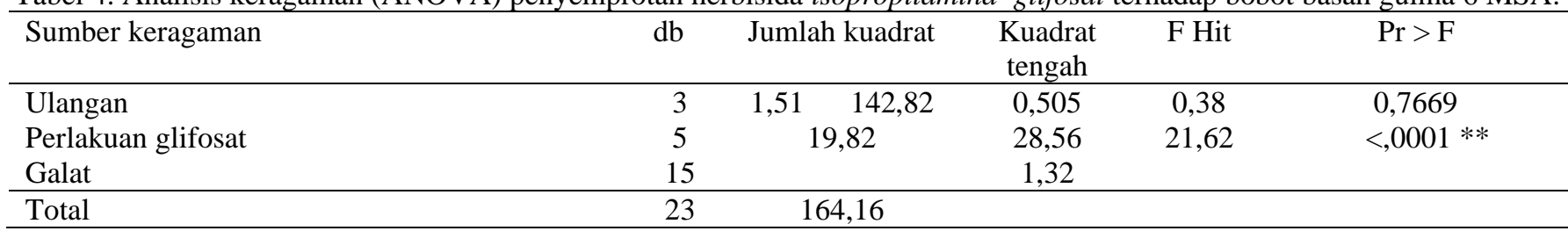

$\mathrm{Kk}=6,759 \%$

Keterangan : Jika P Value <alpha 0,05 maka berpengaruh sangat nyata $(* *)$ pada taraf $5 \%$.

Tabel 5. Analisis keragaman (ANOVA) penyemprotan herbisida isopropilamina glifosat terhadap bobot kering gulma 6 MSA.

\begin{tabular}{lcccccc}
\hline Sumber keragaman & $\mathrm{db}$ & Jumlah kuadrat & $\begin{array}{c}\text { Kuadrat } \\
\text { tengah }\end{array}$ & F Hit & Pr $>$ F \\
\hline Ulangan & 3 & 1,67 & 0,55 & 0,56 & 27,86 & 0,6499 \\
Perlakuan glifosat & 5 & 138,64 & 27,72 & & $<, 0001^{* *}$ \\
Galat & 15 & 14,93 & 0,99 & & &
\end{tabular}

\begin{tabular}{lll}
\hline Total & 23 & 155,24 \\
\hline
\end{tabular}

\section{$\mathrm{Kk}=7,384 \%$}

Keterangan : Jika P Value <alpha 0,05 maka berpengaruh sangat nyata $(* *)$ pada taraf $5 \%$.

Tabel 6. Perbandingan bobot basah dan kering gulma pada pengamatan 2 MSA dan 6 MSA

\begin{tabular}{|c|c|c|c|c|c|c|}
\hline \multirow{2}{*}{ No } & \multirow{2}{*}{ Perlakuan } & \multirow{2}{*}{ Dosis L/ha } & \multicolumn{2}{|c|}{ Sebelum di oven } & \multicolumn{2}{|c|}{ Sesudah di oven } \\
\hline & & & $2 \mathrm{MSA}$ & $6 \mathrm{MSA}$ & $2 \mathrm{MSA}$ & $6 \mathrm{MSA}$ \\
\hline 1 & $\mathrm{~K}_{0}$ & Kontrol & $29,824 a$ & $22,3275 a$ & $23,438 \mathrm{a}$ & $18,7563 a$ \\
\hline 2 & $\mathrm{~K}_{1}$ & 2,00 L/ha & $20,865 b$ & $16,3000 b$ & $18,100 \mathrm{ab}$ & $13,0975 b$ \\
\hline 3 & $\mathrm{~K}_{2}$ & $2,25 \mathrm{~L} / \mathrm{ha}$ & $20,805 b$ & $16,5700 b$ & $18,745 b$ & $12,7400 \mathrm{bc}$ \\
\hline 4 & $\mathrm{~K}_{3}$ & $2,50 \mathrm{~L} / \mathrm{ha}$ & $20,373 b$ & $16,2475 b$ & $18,336 \mathrm{~b}$ & $12,6450 \mathrm{bc}$ \\
\hline 5 & $\mathrm{~K}_{4}$ & $2,75 \mathrm{~L} / \mathrm{ha}$ & $21,625 b$ & $15,6550 b$ & $18,758 b$ & $12,4288 b c$ \\
\hline 6 & $\mathrm{~K}_{5}$ & $3,00 \mathrm{~L} / \mathrm{ha}$ & $23,728 b$ & $14,9325 b$ & $20,979 b$ & $11,3988 \mathrm{c}$ \\
\hline
\end{tabular}

Keterangan: Angka-angka yang diikuti dengan huruf yang sama pada satu kolom tidak berbeda nyata pada DMRT taraf $5 \%$. 


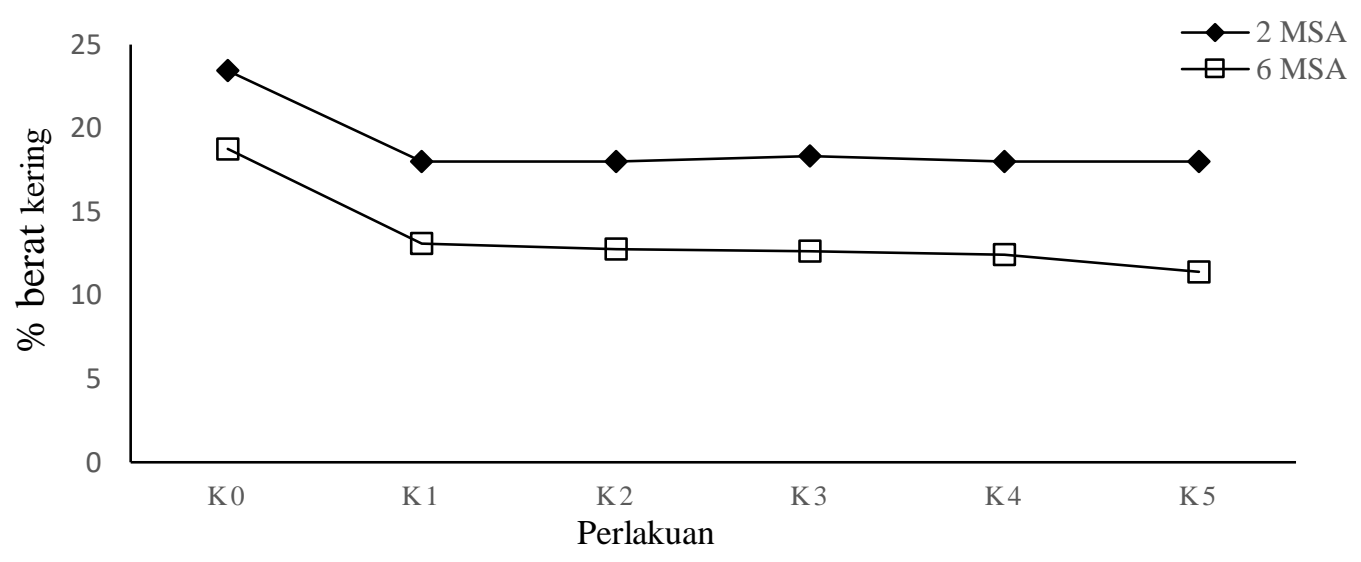

Gambar 3. Rerata berat kering gulma pada berbagai perlakuan

Hasil analisis menunjukkan berbagai macam jenis gulma yang diberi perlakuan dengan herbisida glifosat memberikan pengaruh nyata dan sangat nyata terhadap bobot basah dan bobot kering gulma di lahan penelitian. Data bobot kering gulma dan persentase keracunan terlihat bahwa herbisida glifosat mampu menekan pertumbuhan gulma, dimana pada perlakuan $\mathrm{K}_{0}$ tidak berbeda nyata terhadap perlakuan $\mathrm{K}_{1}, \mathrm{~K}_{2}, \mathrm{~K}_{3}$, dan $\mathrm{K}_{4}$, tetapi berbeda sangat nyata pada perlakuan $\mathrm{K}_{1}$ dengan perlakuan $\mathrm{K}_{5}$, namun jika di lihat dari dosis yang digunakan semakin tinggi dosis maka semakin kecil bobot kering yang dihasilkan, tetapi jika dilihat dari segi efisiensi biaya maka lebih baik menggunakan dosis yang lebih rendah karena dosis 2,00 L/ha sudah mampu menekan pertumbuhan gulma.

Pengamatan persentase keracunan gulma total secara visual dengan melihat dan menduga persentase keracunan gulma total ternyata memiliki data yang sejalan dengan data bobot kering gulma yang dihitung dengan menimbang gulma yang diambil dari petak contoh yang berbeda, mencakup gulma yang terlihat secara visual dan gulma yang tertutupi.

Hal ini menunjukkan bahwa herbisida glifosat mampu mengendalikan gulma. Herbisida glifosat yang telah ditranslokasikan ke seluruh bagian gulma terutama pada bagian akar yang dapat menyebabkan kematian gulma secara efektif. Selain itu, herbisida glifosat mampu bertahan lama di dalam tanah, bahkan saat pencucian oleh air hujan tetap aktif sehingga mampu menekan pertumbuhan gulma lebih lama.

Berdasarkan gambar di atas (Gambar 3) dapat dilihat yaitu semakin tinggi dosis maka semakin kecil berat kering yang dihasilkan. Bobot kering gulma total merupakan jumlah gulma yang terkendali dari gulma golongan daun lebar dan rumput. Gulma yang terdapat di petak perlakuan di dominasi oleh gulma golongan daun lebar. Hasil penelitian menunjukkan bahwa pada 2 MSA dan 6 MSA terhadap semua perlakuan serta perlakuan kontrol mampu mengendalikan pertumbuhan gulma total. Hal ini terlihat dari hasil rerata bobot kering gulma yang terlihat adanya penekanan yang tinggi terhadap pertumbuhan gulma total masing-masing sebesar 3,16\% pada 2 MSA dan 2,25\% terhadap hasil bobot kering gulma $6 \mathrm{MSA}$.
Hal ini juga sesuai dengan hasil penelitian Pasaribu et al. (2017) bahwa herbisida glifosat 5,25 L/ha lebih efektif dalam mengendalikan gulma bila dibandingkan dengan glifosat 2,25 L/ha. Memperhitungkan segi efisiensi dan nilai ekonomi maka taraf dosis yang terbaik merupakan dosis terendah bila dibandingkan dengan perlakuan dosis yang lainnya atau yang lebih tinggi.

Hasil penelitian (Sriyani, 2010) menunjukkan bahwa herbisida mampu menekan pertumbuhan gulma dalam waktu yang cukup lama hingga 3 bulan setelah aplikasi. Secara umum perlakuan herbisida dengan dosis rendah yaitu 1,5 L.ha ${ }^{-1}$ merupakan yang paling efektif apabila dibandingkan dengan perlakuan lainnya. Selain itu, perbedaan bobot kering gulma total pada perlakuan dengan dosis 1,5 L.ha- ${ }^{-1}$ dengan perlakuan kontrol perbedaannya sangat terlihat. Bobot kering gulma rumput total perlakuan kontrol jauh lebih besar dari perlakuan dengan dosis 1,5 L.ha-1 (Supawan, 2013).

\section{KESIMPULAN}

Aplikasi herbisida isopropilamina glifosat dosis 2,00 L/ha-3,00 L/ha menunjukkan pengaruh nyata dan sangat nyata terhadap persentase keracunan gulma dan bobot kering gulma. Tingkat kematian gulma terlihat sangat nyata 6 hari setelah aplikasi mencapai $20 \%$, pada berbagai perlakuan dosis herbisida isopropilamina glifosat yang digunakan. Herbisida isopropilamina glifosat dosis 2,00 L/ha merupakan dosis terbaik dan mampu menekan pertumbuhan gulma secara efektif dengan konsentrasi 1,7\% dalam menurunkan bobot kering gulma total pada 2 dan 6 MSA di tanaman kelapa sawit belum menghasilkan (TBM).

\section{DAFTAR PUSTAKA}

A, R. C., Baillie, B. R., Thompson, D. G., \& Little, K. M. (2017). The Risk Associated with Glyphosate-Based Herbicide Use in Planted Forest. Forest Journal, 8(208), 1-25.

G, S. I. (2013). Efektivitas Herbisida IPA Glifosat 486 sl
untuk Pengendalian Gulma pada Budidaya 
Tanaman Karet (Hevea Brasiliensis muel. Arg) Belum Menghasilkan. Bogor: Institut Pertanian Bogor.

J, M. (2010). Pengantar Ilmu dan Pengendalian Gulma. Jakarta: Rajawali Press.

J, S. D. (2010). Gulma dan Pengelolaannya. Yogyakarta: Graha Ilmu.

N, S. (2010). Pengelolaan Gulma dan Herbisida untuk Meningkatkan Produktivitas Lahan Pertanian Secara Berkelanjutan. Lampung: Fakultas Pertanian
Universitas Lampung.

Pertanian, K. (2013). Pengelolaan Gulma pada Perkebunan Kelapa Sawit.

R, P., P, W. K., \& Y, T. S. (2017). Uji Lapang Efikasi Herbisida Berbahan Aktif IPA Glifosat 250 g.L-1 Terhadap Gulma Pada Budidaya Kelapa Sawit Belum Menghasilkan. Jurnal Produksi Tanaman, 5(1).

Y, F., Widyastuti, Y. E., Satyawibawa, I., \& Paeru, R. H. (2012). Kelapa Sawit. Jakarta: Penebar Swadaya. 